\title{
Islamization of Science
}

\author{
REHAF A. MADANI ${ }^{1}$
}

\begin{abstract}
The Islamization of Knowledge process is considered as one of the most important and intellectual movements of the $20^{\text {ih }}$ century. It is also one of the most credible and longstanding contemporary Muslim intellectual responses towards modernism. The undefined structure and framework of the Islamization process makes it a challenging task and recognized more as a theory rather than effective methodology plan. This paper focuses on the Islamization of Knowledge in general, comprising with its history, definition and pioneers. Moreover, Islamization of science subjects in specific with the objective of introducing a framework for this phenomenon, based on Al-Farouqi's 12step work-plan and Berghout's framework using a descriptive theoretical theory.
\end{abstract}

Keywords: Islam \& science, Islamization, knowledge, science

Previously, Muslim scholars successfully led the world with their knowledge and scientific advancements that emerged after an in-depth study, translation and foundation on the writings of the early Greek philosophers. Later in the fifteenth century, the Muslim civilization witnessed a decline in its motivation to seek knowledge, while the western civilizations, on the other hand, rose by building its intellectual base from the Muslim institutions (Setia 2007; Ahsan 2013) Niyozov \& Memon (2011) argued that Islamic education has reached a crossroad lately, while Islamic scholars need to make a crucial decision to invest in the collaboration with present "modern or western knowledge".

The Islamic entities require firm and complete collaboration in future so they can lead Islamic nations to triumph and align with practices of new millennium, as it is not feasible enough to rely on the past. Due to the circumstances, which Muslim communities are experiencing, it is a perfect time now to support an interaction with modern knowledge rather than to adopt a rejectionist attitude. Collaborative approach in Islamic practices would be able to provide comparative advantage to both, Islamic and non-Islamic, schools of thoughts.

Over the past decade, with an ongoing scientific advancements and breakthroughs, Muslim and non-Muslim scholars have realized that modern scientific knowledge is specific to the Western civilization in terms of values and concepts. The significant fact of knowledge influenced Muslim scholars to the principle and idea of "Islamization of Knowledge" (Rehman 2003). In 1997, the first international conference on Islamic Education was held in Makkah, Saudi Arabia. The conference argued and integrated knowledge from an Islamic perspective where Muslim scholars have put in huge efforts and suggested different approaches to collaborate Islamic values and ethics in various fields of modern thought (Zaidi 2006; Haneef 2005). Since then, many developments have been initiated along with the development of discipline in theory and practice. The concept of Islamizing

\footnotetext{
${ }^{1}$ Rehaf Anas Madani, Ph.D. candidate at Faculty of Education, the British University in Dubai, Block 11, $1^{\text {st }}$ and $2^{\text {nd }}$ Floor, Dubai International Academic City, P.O. Box 345015, DUBAI, United Arab Emirates, email: rehafmadani@hotmail.com.
} 
modern sciences has been a center of interest among many Muslims scholars and intellectuals. In fact, it is now considered as one of the most important intellectual movements of the $20^{\text {th }}$ and $21^{\text {st }}$ century and one of the most credible and long-standing contemporary Muslim intellectual responses towards modernity.

The concept of Islamization of Science is approximately thirty years old. During this period, there have been multiple studies, discussions, books, articles and seminars were proposed widely, which aimed to clarify the idea in a conceptual and pragmatic term. As an example, The American Journal of Islamic Social Sciences has been regularly publishing articles that deal with the theme of Islamization in general and social sciences in particular.

However, despite the enthusiasm, the works have stayed to a limit when counting number of proposed ideas of different individuals, institutions or school of thoughts. Furthermore, little progress has been achieved due to an un-unified agreement on the actual concept of Islamization and the lack of a professional agreement on framework, as each Muslim scholar argues from a different perspective (Setia 2005).

Unfortunately, the weak economic and political position of Muslim society around the globe have instituted more pressure to follow western knowledge and modernity in all aspects (political, economic, social and educational), which resulted in the penetration of western cultural and philosophical thoughts and values (Zaidi 2006).

In the field of education, there has always been a misunderstanding in the relationship between science and Islamic worldview. This aspect raised two significant questions. First, due to the misapprehension of key terms and their content by which is considered as science? Second, which is Islam? The main lesson gained from the IOK project is that Muslims did not fully discuss and understand the philosophical and methodological issues of the modern disciplines, which they continuously kept on commenting on and trying to Islamize. Bakar (2003) argues that science should be approached as a theoretical assembles consisting of four components: the body of knowledge, basic hypothesis, methods of study and finally the goals. Proceeding, all four components should then be studied and viewed in the domain of Islam. To gain an understanding on the Islamic critique on modern science and to understand the relation of it with Islam, it is important to acknowledge that without parallel the Holy Quran has a major influence on Muslim mind and their global community (Guessom 2008).

There are various commitments made by researchers composing on IOK project. The objective of this paper is to figure out the best outcome of drawing up a relationship between modern science and Islam in terms of Islamic perspective. By discussing previous attempts already made by selected and pioneered Islamic scholars, which in the early 1980s discussed the Islamization of Knowledge project (IOK) concentrating on its beginning and improvement. This comprise with discussions such as goal of IOK, the importance or significance, procedure of IOK and role of IOK in contemporary grant and writing.

The aim of this article is to provide a framework for the development of Islamization in general and Islamization of modern science in specific too. The article will be categorized into several categories; first section will include the theoretical framework, which will even include a proposed work-plan for the Islamization of science in specific. It will also shed light on the literature review, including the meaning of IOK project, its origin and development. Second, it will discuss the history of IOK; third, it will include a discussion regarding perspectives and inputs of selected Islamic scholars and pioneers. The second section will include methodology, while third section will involve the discussion and interpretation of paper, and finally the conclusion will be given where comments on Islamization of Education on the premise of the substance will be exhibited. 


\section{Theoretical Framework}

Despite the fact that the Islamization of Knowledge project has become attention-seeking phenomenon of many Muslim scholars for past thirty years, there is no agreement done on neither framework nor a definite methodology plan for the process of Islamization of Knowledge in general or the Islamization of science in specific. The disagreement still exists at extreme, even after thirty years of focus. The concept of Islamization of Knowledge is still considered to be in its theoretical stage, as each scholar carries a different perspective and a different methodology or plan of work.

After viewing many work-plans of different scholars, combination of both al-Faruqi's (1988) twelve-step plan and Berghout's (2011) framework is found to be the most suitable work-plan for the scope of this research. In this section Alfarouqi and Berghout's theories and models that deal with the Islamization process will be in complete discussion with an objective of developing a theoretical model of Islamization of Knowledge to be used within the context of science subjects, which will provide an opportunity to create a combined phase of modern sciences and, Islamic values and ethics.

Figure 1: Proposed Framework for the Islamization of Science subjects

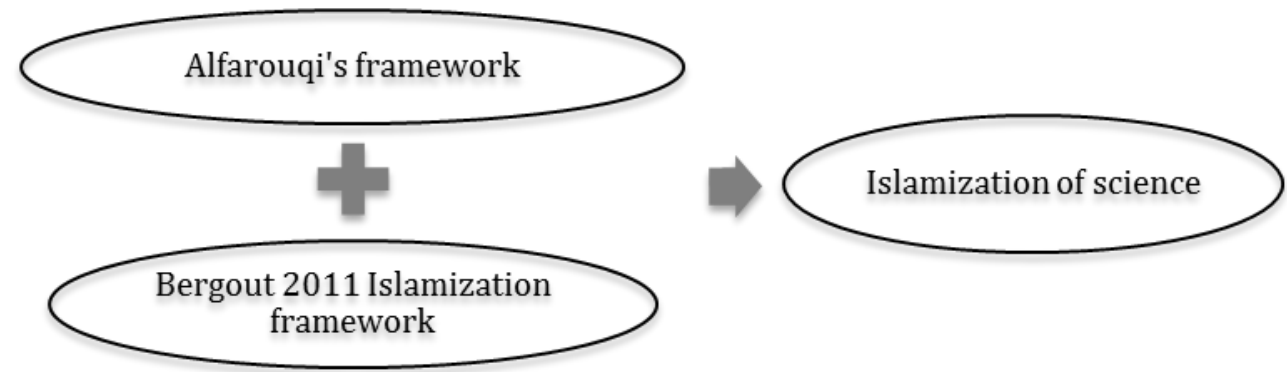

Figure 2: Detailed Description of the proposed Islamization of Science Subjects Framework (the proposed module's diagram represents the two different theories and modules used for the framework of the proposed study as discussed below)

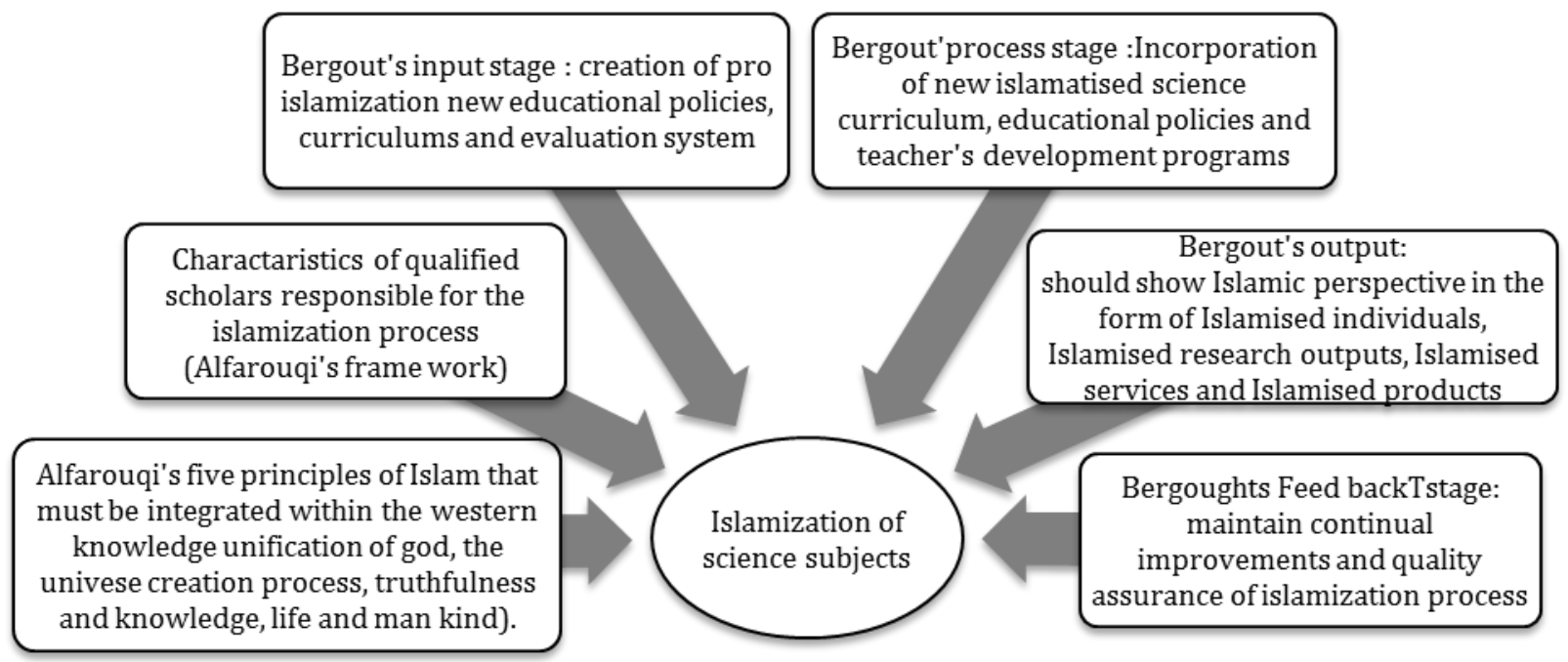


In al-Faruqi's (1988) work-plan, he gave a sufficient outline that will assist the approaches to deal with the Islamization of Knowledge as a principle. This is a primary standard known as the "Reconstructionist approach". Considering the principles of this methodology, humanities and sociologies ought to be discriminatingly examined and released from the Western-based philosophies.

The second approach, grew by the Office of Preliminary Societies of the Encyclopaedia of Islamic Sciences is known as "Fighati's New Sociology". According to this methodology, choosing the best path, attaining greatness and looking for pleasure for humanity and sociologies by God, they must find perfect standards; a perspective bolstered by Ayatollah Khamenei in his discourses. The third approach is to study the social contemplations in their works. As evidence, Muhammad Husayn Tabatabaei, entity comprising with an overwhelming commitment to the revival of Islam, Islamic theory and Tafsir (al-Farooqui 2002).

Al-Faruqi was the first scholar to outline the Islamization project as he identified the five principles of Islam, which have to integrate within western knowledge (the unification of: God, the whole of creation, truthfulness and knowledge, life and humanity). From these principles, al-Faruqi established a five-step outline for Islamization (Haneef 2005):

1. To be an expert in modern science.

2. To be an expert in Islamic knowledge of those fields.

3. To demonstrate the relevance of Islam to modern disciplines.

4. To compare and relate Islamic values and ethics with modern social sciences.

5. Introduction of an Islamic thought that aligns with Muslim values and ethics.

These five main steps were later expanded to a 12 point framework (al-Farouqi 1988; Zaidi 2006; Ahsan 2013). In this work-plan, both the Islamic and the western knowledge may be described as a double integration process as it requires the renovation of both modern and traditional Islamic knowledge.

1. Mastery of modern disciplines: breakdown of the table of contents list in modern textbooks of specific area.

2. Discipline overview that shows the history, approach and primary patrons of that specific area, including a reference index.

3. Mastering the Islamic legacy: The Anthology, in this point, the items or endeavours in steps 1-2 will give the premise to making collections from the legacy organized by classifications of that area of interest.

4. Mastery of the Islamic legacy: The Analysis, this is more of an inside and out perspective, which is organized principally, recorded examination of approaches through which Islamic legacy contributed, and was deciphered into medicines for activity.

5. Establishment of the particular significance of Islam to the orders covering what the legacy has added to the scope of issues imagined by the order, the legacies accomplishments and deficiencies opposite the 'vision and extent of the control', why it is so and what should be possible.

6. Critical evaluation of the advanced order: The State of the Art includes a basic appraisal of control from the stance of Islam and is seen by al-Faruqi as a noteworthy stride in IOK. It includes an assessment of control taking into account Islamic criteria; however, with information of the innovative tech, its history and advancement and so on subsequently creating authentic best in class covers the orders being referred. 
7. Critical appraisal of the Islamic legacy: The State of the Art, which includes a basic assessment of the translation of Muslim researchers of the wellsprings of learning in Islam versus the sources themselves, distinguishing qualities, deficiencies and conceivable routes forward.

8. Survey of the Ummah's real issues obliging knowledge, practical insight and information of both the legacy and current learning.

9. Survey of the issues related to humanity, since IOK is seen to be for Muslims as well as for all humankind.

10. Creative examination and blend between the Islamic legacy and present day orders mulling over both should be reliable according to Islamic vision, confirming its pertinence to the issues of today.

11. Recasting the orders under the system of Islam: The University Textbook as a substitution or if nothing else a supplement to the standard course book utilized as a part of a specific control.

12. Dissemination of Islamized Knowledge where thoughts and considered Muslims included in IOK must be accessible to all.

Berghout's (2011) framework or model of Islamization on the other hand, is an adapted version of the quality-management system model, with the aim of developing an implementation approach while enhancing the process of Islamization within universities in order to guarantee its success. In this model, Berghout views Islamization as a quality process, consisting of input, procedure, output and a response. To ensure the effectiveness of the Islamization process on the entire activity of learning, Islamic perspectives are incorporated in all parts of the suggested framework including the input, procedure and the output.

In the Islamization of science framework, Berghout concentrates on fulfilling three essential domains of progression of a learner namely intellectual, psychomotor and affective, with greater emphasis on the affective part in all three domains.

Figure 3: Berghout's (2011) Model of Learning within the Islamic Framework Perspective

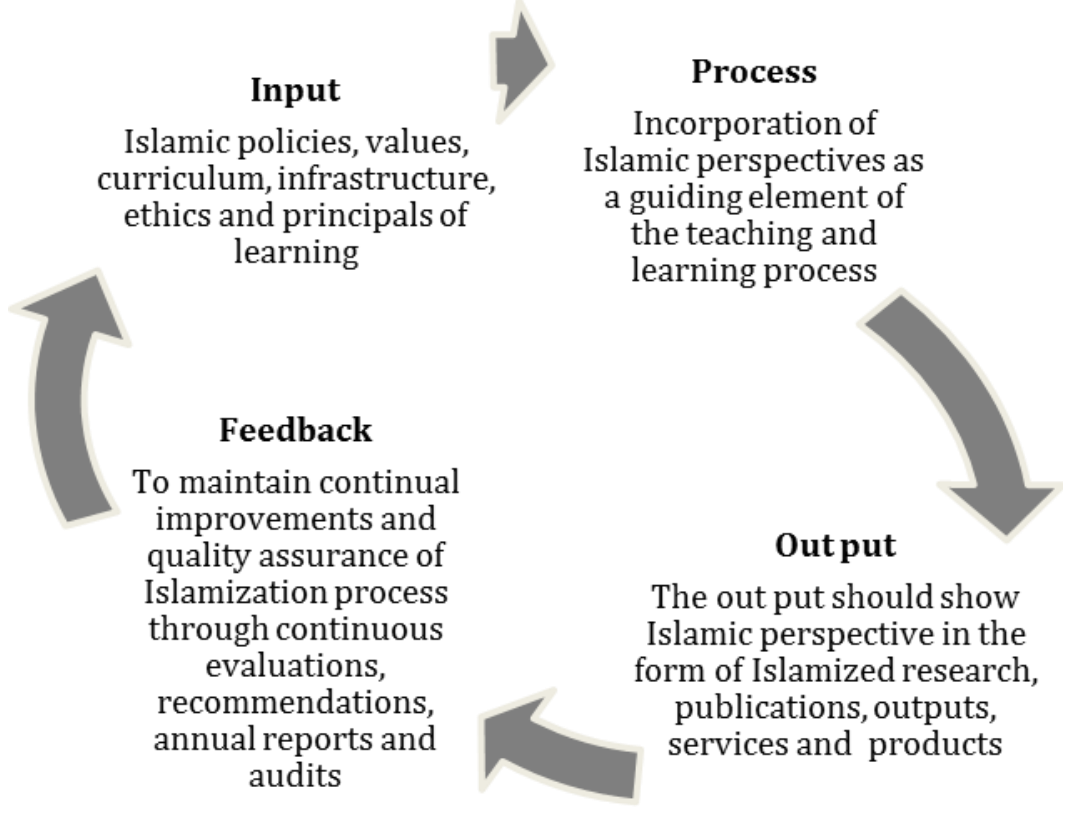

https://doi.org/10.24035/ijit.9.2016.006 
In the above illustration Islamic policies, curriculum, values, ethics and principals of learning are all integrated within the phase of input. Similarly, in the phase of process, Islamic perspectives are playing an incorporated role as a guiding element of process of teaching and learning, while the output phase should demonstrate Islamic perspectives. Moreover, it is important to pay attention to feedbacks in order to maintain continual improvement and quality assurance.

\section{Literature Review: The Meaning, Origin and Development of Islamization of Knowledge}

It is becoming a social reality with passage of time that Muslim society is inputting their maximum efforts in order to find Islamic roots, along with extreme desire to restore dominant Islamic Civilization around the globe. Few distinct jargons such as Islamic Renaissance, Islamic Revivalist Movement, Islamic Reformation and Islamization of Knowledge are mentioned that defines the significance and motivation behind the social phenomenon, with remarkable attention to both Muslim and Non-Muslim universes in 20th and 21st centuries. In this widely spread socio-social connection, various scholarly Muslim individuals argued that removing the discomfort that overruns Muslim social orders requires two aspects. The aspects are firstly, the acknowledging an advancement in context to Weltanschauung and secondly, the reproduction of information that supports Western strength.

The term Islamization alludes to align and compose transformations intended to enhance the individual and society by adjusting them to Islamic standards. It gives off an impression of being synonymous with the term Islamic Revivalism (Renaissance), which is characterized as a change situated development driven by a cognizant change in Muslim thoughts, dispositions, conducts and further described as a pledge to revive Islamic Civilization. Many reformists share different perspectives and opinions in regards to the meaning and ways of Islamization of Knowledge.

Ahsan et al. (2013) even argued that there are three noteworthy powers constituting to this development: First, reformism that alludes to strengths that have a tendency to change Muslim society by transforming people with the assistance of the essential social organizations. Second power is activism that alludes to a political development. Third, intellectualism, which alludes to the development of Islamization of learning that moves and spurs Muslim educated people to progress, advance and spread information, to look for reorganization of Muslim thought, Islamic approach and to encourage Islamic change of Muslim groups in Muslim moreover non-Muslim nations.

Berghout (2011) defines Islamization as a scientific activity or an experimental action done to attain the revival of scholarly and civilized viability of Muslim brain and society. Moreover, the author emphasized on the importance of creating a relationship with western knowledge in order to ensure and maintain the quality and direction of entire activity based on which, this phenomenon is applicable. Imad al Din Khalil defines Islamization as a scholarly movement by taking the Islamic idea of life, man and universe into intense consideration (Ahsan et.al 2013). Dangor (2005) argued that the project of Islamization requires the reevaluation of the Islamic history, its background and the development of a new epistemology or theory, which is in alignment to its methodology, logic and rationale.

Mona Abul-Fadl (1988) describes Islamization as a process of transformation and revitalization of present and basic structure of thought and recognition by method of their introduction to a radical evaluation in the light of a coordinated arrangement of intellectual, emotional and typical qualities obtained from the Islamic custom. Ali (1999) reviews the Islamization process as methodological movement or an investigation of various differentiations, 
which justifies belief from opinion in favour of human development. Stenberg (1996) defines Islamization as "the deliverance of knowledge from its interpretations based on secular ideology and from meanings and expressions of the secular".

Rahman (2011) on the other hand, stated that IOK could not be achieved by adding modern science to one that is old and traditional excising. The author believes that Islamization of education can only take place if governments and concerned regulatory of Islamic countries apply Islamization as an educational policy that can only be achieved by highly educated academics with an Islamic knowledge background and characteristics. Iqbal (1997) agrees that Islamization of Knowledge should not play a role of dependent on present Islamizing disciplines. The author emphasis was based on the significance of Muslim scholars input and independence. Furthermore, Lotfalian (2001) portrays knowledge as continually being great and the issue is its misuse. He raised a question on scholars and reformers to first study our own Muslim customs in the light of the Holy Quran and Sunnah before reviewing western knowledge or modernity.

\section{History of Islamization of Knowledge}

In the limelight of broadest perspective, stakeholders can assume that the history of IOK began from disclosure of the holy Quran. The Prophet Muhammad (peace be upon him), utilized learning to achieve changes in contemplations, mentality and practices of individuals and after achieving each one of them perfectly, he built up the first Islamic group of spiritual foundation. This foundation strictly emphasized the importance of knowledge for strength, growth and advancement of Muslim nation in every corner of the world. Since then, Muslims have been enthusiastically seeking maximum knowledge from all over the world, which lead to the golden age of Islamic civilization. Muslim pioneers as al-Biruni, al-Khawarizmi, Ibn al-Haytham, Ibn Sirrin, alKindi, Ibn Khaldun, Ibn Sina and many other personalities built the base of modern science (Guessoum 2008). This section will discuss the history and origin of the Islamization process and its progress.

Nonetheless, the decline of Muslim's hunt for knowledge in $15^{\text {th }}$ century held back the entire nation of Islam, while the western or modern knowledge reached its level of optimum and excellence. It was not attained until the second half of the 18th century when the Muslim political reform took place by many different reformers. These political reformations have influenced the change development of the Muslim nation in the 19th and mid-20th Centuries: Sheykh Mohammad Ibn Abd al-Wahab in the Arabian Peninsula; The Sunni Movement in North Africa; The Mahdi Movement in Sudan; Midhat Pasha in Turkey; Khayri-i-Din Pasha in Tunisia; Malikum Khan in Persia; Sayyid Ahmed Khan, and;Amir Ali in India.

Unfortunately, throughout these movements, little consideration was given to the core of the crisis, which is the emergency of thought as well. It was not until a group of Muslim college students studying at the United States of America (USA) initiated the historical re-evaluation and reassessment of diverse Islamic advancements in the Muslim world that provided innumerable opportunities to the idea of Islamization of Knowledge. The young Muslim pioneers considered this reassessment as their need to address the renewal of thought and the incorporation of Western accomplishments in technique with Islamic qualities and convictions.

The establishing of the Association of Muslim Social Scientists was a stage in this course, since it was built up in 1972. The attempts of young individual Muslim pioneers came on a condition of flawlessness in the establishment of the International Institute of Islamic Thought (IIIT) under the organization of Isma'il Ragi al-Faruqi. The Institute was formally melded in the 
United States of America in 1981 and immediately had a tendency to tie itself to the issue of Islamic thought and Islamization of Learning.

However, six international conferences have been held to discuss and debate the issues of Islamization until date today. Starting with the first conference in 1977, it held in Saudi Arabia in order to support the importance of establishing a research institute and emphasized the importance of updating the basis of academic and Islamic thoughts for the process of Islamization. In 1980, the second conference was held in Pakistan to encourage social Muslim scientists to the process of Islamization of their disciplines. Further, in 1981a conference was held in Bangladesh to justify the establishment of textbooks regarding the Islamization project. In Indonesia during 1982 and in Egypt during 1987, various conferences were held to support previously proposed topics in other countries. Finally, year 1996 in South Africa, a conference was held to concentrate on the importance of developing a curricular syllabus and guidelines in primary and secondary educational levels for Muslims, as well as designing in-service teacher development programs.

\section{Perspectives and Inputs of Selected Pioneer Islamic Scholars on the Islamization of Kowledge (IoK)}

Related literature on the Islamization of social sciences and humanities convincingly concur that either sociologies need to integrate with the Islamic parameters of social life or, it should be reconstructed within the Islamic parameters of social life. During the last two decades, the quantity of Islamic schools has been expanding across the world as it was seen in the United States, Europe, South Africa and other nations. This worldwide development has emphasized the need of the Islamization venture to present Islamic morals and ethics to its students. Individual Islamic Scholars including Isma'il al-Faruqi, Syed Husain Nasr and Fazlur Rahman, first established the Islamization project in the United States as a reaction to the secularization of Muslim society, including its educational institutions.

The IOK project was originally established by Abdul-Hamid Abu-Sulayman in the late 1960s, where he played a powerful and dominating role in The Association of Muslim Social Scientists in the United States in 1971 along with Isma'il al-Faruqi, Euben (2002) completed an assessment on IOK project, conducting that it is still in "its pre methodological" stage, where the IoK must be viewed as an epistemological and methodological concern. According to perspective of Safi, Al-Faruqi's 12-point work-plan is an overpowering and logistically hard to accomplish. Subsequently, he proposed a total distinct methodology, which highlighted the likelihood of revamping the 12-point work-plan into two parallel tracks. First track is managing advanced information and its philosophies and other track is managing the Islamic legacy and its procedures.

Other Muslim scholars (e.g. Ragab 1999; al-Faruqi, 1988) provided arguments in favor of an Integration of the humanities and social sciences with certain Islamic traditions. In accordance to their point of view, only some part of Western-based traditions, contradict with the Islamic value system and Islamic principles. However, technique to apply this integrationist approach is a matter of debate and scholars in this camp adopt different strategies.

Naqib al-Attas (1978; 1980) proposes a two-step plan to Islamize modern and/or contemporary knowledge. First step is the isolation process, where the isolation of western culture and values takes place. The second step is the infusion of this knowledge with Islamic features. On the other hand, Ragab (1999) believes that there are two approaches to Islamizing the social sciences; first by 'engagement' and secondly by 'disengagement'. The 'engagement' group assumes that modern knowledge still has a valuable role in the Islamization process, while the 'disengagement' group totally rejects the integration between Islamic and Western traditions of 
scholarship.

Imad al-Din Khalil states that the process of IoK requires two levels. First, the theoretical phase, which clarifies aspects such as measurements, intentions, points, stages and related methods for IOK in context to Islamization. Secondly, the implementation phase where the process of Islamization of different subjects takes place by specialist scholars for each subject (Ahsan, et.al, 2013). Further, Tayyebi (2015) describes that nearly all the scholars and researchers approach the issue of Islamization in the following way: first by criticizing the Western-based knowledge, secondly by exploring the relevant Islamic parameters and finally by providing a strategy, methodology and epistemology of either an Integration of the two perspectives or a Reconstruction of the disciplines.

\section{Methodology}

This paper is a descriptive theoretical study, as the main approach used is viewing previous literature that relates to the scope of this topic, which is the Islamization of Knowledge process (IOK). A descriptive research reviews the circumstances of topic, its policies, tradition, structures, and existing differences in various aspects, conceptions, operations and directions (Sandelowski 2000).

Toury (2012) describes a descriptive case study or a descriptive theory as one that is centered and detailed, where an already known phenomenon such as Islamization is carefully described and comprehended. This research is based on the literature and findings of previous studies including proposals of Iqbal (1997) - The Islamization of Science; Ragab (2013) -A Significant Component of the Islamization of Knowledge Effort; Ahsan et al. (2013) -Islamization of Knowledge: An Agenda for Muslim Intellectuals, and; Farooqui (2002) -Towards an Islamic Sociology.

The framework of this study is based on combining proposed Islamization work-plans of two intellectual pioneers, Al-Faruqi's (1988) -Islamization of Knowledge: Problems, Principles, and Prospective and Berghout's (2011) -Islamisation in Modern Sciences: The Way Forward.

\section{Discussion}

Major critiques towards the process of Islamization is mostly concerned with the fact that some writings and literature on this subject matter can be viewed as hostile to Western culture and could be depicted as regretful (Taskin 2014). Furthermore, neither the standards of an Islamic epistemology for normal and human sciences, nor the standards of an Islamic approach have been clearly defined. Despite the fact that the Islamization project has started approximately four decades ago, only six international conferences were held so far. Moreover, there is inadequate amount of reading material on the Islamization of Knowledge topic has yet been developed (Dangor 2005). Considering these critiques and professional assessments of adequacy, it significantly helped in deciding on proposal development of a framework for this study. Since the proposed framework aids in overcoming popular weaknesses of the Islamization process and aid in transforming its theory to an implementation process with utmost anticipation.

In this section, the proposed framework of the study in regards to the Islamization of science will be fully discussed, including the relation between the two combined frameworks of AlFarouqi and Berghouts work-plans. It will also take all the potential similarities, differences and critiques into account as well.

After analyzing and searching through many different work-plans and perspectives of different Islamic scholars and pioneers, an individual could not be able to deny that Al-Farouqi (1988) concentrated more on the characteristics of scholars in his work-plan that can execute the 
process of Islamization and lacked the description of exact methodology and steps, which are specifically related to the procedure.

Berghout (2011) on the other hand, developed a methodological work-plan for the execution of Islamization of science in specific, by adapting the quality-management system model without providing availability of extra details, or attention to characteristics and prescriptions of an executer. Henceforth, despite the wide timeframe difference between both models, in one way, they both completed or complemented each other.

In response to the critic of the Islamization project being aggressive to western or modern knowledge, both selected frameworks are found to be reliable on modern science. Berghout (2011) emphasizes the importance of referencing back to the western knowledge in order to ensure and maintain the quality and direction of the whole activity. Even though Al-Faruqi calls for the reconstruction of modern science, claiming that Western social sciences are troublesome and can negatively affect Muslims, his twelve-step work-plan relies heavily on Western knowledge as the basis of information.

Despite his criticisms on modernization, al-Faruqi encourages Muslim scholars to integrate modern knowledge within Islamic values by modifying, eliminating, revising and clarifying its components. The first approach or system for Islamization of humanities and sociologies upheld by al-Faruqi may be the most adequate one to the Muslim researchers in social science, however some may assert it is not adequately Islamic.

Steps 1-3 in Al-Farouqi's work-plan are unmistakably purposes of dispute that are genuinely reprimanded. The way that the "standard tables of substance of cutting edge course readings" are made the subjects of reference for which the Islamic legacy will be investigated, is seen to be a noteworthy shortcoming of al-Faruqi's work-plan. Al-Farouqi was one of the first pioneers that called for IOK process. Many of the critiques against his framework were mainly due to the difficulty of its execution. Moreover, claims against al-Faruqi's vision of reconstruction of being shallow and influences by spirit of de-traditional and rationalization of modernity (Zaidi 2006). This can be true if reviewed from specific perspective of humanities and social sciences, but not necessarily in the case of science subjects.

Islamization of Knowledge in general, is a very difficult task with no parameters. Therefore, the completion of this project is considered as one of the extremely difficult task. If not a dream as the heart of its intellectual process involves the Islamization of humanities and social science due to various epistemological, methodological and ontological reasons (Ragab 1999). In social sciences and humanities, Islamization is vital due to the integration of western behaviours and ethics through its distinct social subjects and areas. On the other hand, in the Islamization of science, little behavioural effect is shown because science is more about nature and evidence in reality where there is no room for emotional or social influences, which Islamization of science highly comprise. For example, chemistry is all about the reaction between different elements, without any potential regards to cultural, ethical or behavioural issues.

In proposed framework of his study, Berghout describes that by captivating the Muslim mind into a revelation trip of the experimental laws, it will encourage it to dig further into a more profound request of what is past the physical laws. It cannot be overlooked by Islamic scholars and stakeholders that this is the initiating stage of the procedure of Islamisation of science. Likewise, inside of this incorporated system, the Islamisation of science will provide a required driving force to scientists, based on which, they will conduct new and investigative learning with reason and bearing. In addition, the procedure of Islamizing science ought to address the topic of the "Researcher" himself. The self of the researcher in this connection includes his psyche, heart, conscience and profound and moral measurements specifically. 
In conclusion, by combining the two work-plans, first we specified the requirements needed and extracted from different scholars, which identifies them as qualified for participating in the Islamization process from al-Faruqi's (1988) work-plan. Proceeding after extraction of requirements, we can follow Berghout's (2011) work-plan consisting of input, process and output. Based on these frameworks, we would attain both, the qualification and steps of the IOK procedure, which makes the IOK procedure more possible.

Despite the fact that all sciences are society that are significantly bound to each other at some level, the characteristic and physical sciences comprise with limited issue than sciences of sociology, particularly from the perspective of majority Muslim researchers (Sandelwoski 2000). With common sciences, this issue is strongly connected to perspective of nature and rationale of concerned sciences.

On an account of sociologies, the issue is comparatively more intense than in other fields. It concerns not just the general viewpoint of humanity and society, additionally the hypotheses and ideas of these controls (al-Azm 2007). Hence, Muslim researchers are more prominently committed with thoughtfulness regarding the sociologies, which numerous articles and books managing the Islamization of information as a rule, and of the sociologies specifically. These publications have been distributed in couple of decades previously. So far, little progress has been made in regards to unifying different scholars and their respective point of views on the idea of Islamization of Knowledge project (IoK).

The Islamization of Knowledge project has been strongly criticized, opposed and investigated by many Muslim and non-Muslim opponents over the period for reasons discussed earlier. Scholars such as Abdus Salam and Hoodbhoy rejected the idea altogether while others carry a positive perspective with utmost support, encouragement and determination for the process, considering it as the most promising approach to pull the Islamic nation out of its decrease. In general, scientists are indifferent with little notion of the idea and carry no actual intellectual commitment for or against Islamization.

In order to achieve IOK project, it is essential to overcome the theorization phase and move forward to its phases of implementation and evaluation. An un-measureable efforts and resources are simultaneously required to achieve accurate strategic planning and a clear unified strategy where Islamic elements can be infused to the core activities of teaching and learning in order for the project to reach its objectives. While the advancement of an "indigenous" system of learning is reasonable, the issue of Islamization is loaded with obstructions and complexities for an example there has been no official backing for the IoK venture from any governments in the Muslim World (Berghout 2011).

The issue of the IoK project is that the call for engagement between the two different and involved entities, the western scholars and Islamic scholars in regards to the dialog and association must be equally acknowledged. This implies something altogether different from just the acceptance of knowledge in current sciences or the dismissal of ideas that it originates from the west. Maybe, it suggests an intensive assessment and evaluation of western sciences, related approaches of implementation and progress, and subsequent collections of information from Islamic points of view. Likewise, it might be consequently that the IOK venture may be focused by its rivals following any achievement in 'making equivalents in the space of scholarly interest' will positively have a colossal political, financial and social effect. 


\section{References}

Abul-Fadl, M. 1988. Islam as a force of global cultural renewal. The American Journal of Islamic Social Sciences 5(2): 165.

Ahsan, M., Shahed, BA. \& Ahmad, A. 2013. Islamization of knowledge: an agenda for Muslim intellectuals. Global Journal of Management and Business Research 13 (10): 1-11.

al-Azm, S. J. 2007. Islam and the science-religion debates in modern times. European Review. 15(03): 283-295.

Ali, M. 1999. Reconstruction of Islamic thought and civilization: the case of Islamization of knowledge. The American Journal of Islamic Social Sciences 16 (1): 94-101.

Bakar, 0. 2003. Reformulating a comprehensive relationship between religion and science: an Islamic perspective. Islam \& Science 1(1): 29.

Bakar, 0. 2005. Gülen on religion and science: A theological perspective. The Muslim World 95(3): 359-372.

Berghout, A. 2011. Islamisation in modern sciences: the way forward. Revelation and Science 1 (3): 21-34.

Bigliardi, S. 2012. Barbour's Typologies and the contemporary debate on Islam and science. Zygon 47(3): 501-519.

Dangor, S. 2005. Islamization of disciplines: towards an indigenous educational system. Educational Philosophy and Theory 37(4): 519-531.

Euben, R. L. 2002. Contingent borders, syncretic perspectives: globalization, political theory, and Islamizing knowledge. International Studies Review 4 (1): 23-48.

al-Faruqi, I. 1988. Islamization of knowledge: problems, principles, and prospective. In Proceedings \& Selected Papers of the Second Conference on Islamization of Knowledge pp. 13-64.

Farooqui, J. 2002. Towards an Islamic Sociology. Kuala Lumpur: International Islamic University Malaysia.

Guessoum, N. 2008. The Qur'an, science, and the (related) contemporary muslim discourse. Zygon 43(2): 411-431.

Haneef, A. 2005. A Critical Survey of Islamization of Knowledge. Gombak: International Islamic University Malaysia.

Iqbal, M. 1997. The Islamization of science: four Muslim positions developing an Islamic modernity. Islamic Studies 36 (3).

Lotfalian, M. 2001. Knowledge systems and Islamic discourses a genealogy of keywords on the development of science and technology in transcultural context. Cultural Dynamic. 13(2): 231-243.

Niyozov, S., \& Memon, N. 2011. Islamic education and Islamization: evolution of themes, continuities and new directions. Journal of Muslim Minority Affairs 31(1): 5-30.

Ragab, I. A. 2013. Creative engagement of modern social science scholarship: a significant component of the Islamization of knowledge effort. Intellectual Discourse 5(1).

Rehman, J. 2003. Searching for scientific facts in the Qur'an: Islamization of knowledge or a new form of scientism? Islam \& Science 1(2): 245.

Rahman, F. 2011. Islamization of knowledge: A response. Islamic Studies 50 (3/4): 449-457.

Sandelowski, M. 2000. Focus on research methods-whatever happened to qualitative description? Research in Nursing and Health 23(4): 334-340.

Setia, A. 2005. Islamic science as a scientific research program: conceptual and pragmatic issues. Islam \& Science 3(1): 93. 
Setia, A. 2007. Three Meanings of Islamic science: Toward operationalizing Islamization of science. Islam and Science 5(1): 23-52.

Stenberg, L. 1996. The Islamization of science: four Muslim positions developing an Islamic modernity Lund Studies in History of Religions 6: 88-98.

Taşkın, Ö. 2014. An exploratory examination of Islamic values in science education: Islamization of science teaching and learning via constructivism. Cultural Studies of Science Education 9(4): 855-875.

Toury, G. 2012. Descriptive Translation Studies and Beyond. Revised Edition. Vol. 100. n.l.: John Benjamins Publishing.

Zaidi, A. 2006. Muslim reconstructions of knowledge and the re-enchantment of modernity. Theory Culture and Society 23 (5): 69. 